\title{
Proportions and static Analysis of a Historical Truss in a Rural House in Vápenná Village
}

\author{
Peter Krušinský ${ }^{1, *}$, Jozef Gocál ${ }^{1}$, Lucia Augustínková ${ }^{2}$, Eva Capková ${ }^{3}$ and Renáta \\ Korenková ${ }^{1}$ \\ ${ }^{1}$ University of Žilina, Faculty of Civil Engineering, Žilina, Univerzitna 8215/1, Slovak Republic \\ ${ }^{2}$ Technical University of Ostrava, Faculty of Civil Engineering, Ostrava, Ludvíka Podéště 1875/17, \\ Czech Republic \\ ${ }^{3}$ University of Žilina, Faculty of Humanities, Žilina, Univerzitna 8215/1, Slovak Republic
}

\begin{abstract}
We have analysed historical trusses based on previous buildinghistorical researches, particularly focusing on sacral buildings, in chosen regions of Slovakia, with one of the primary goals to examine geometric concepts and proportional relationships used for their construction. The knowledge of proportional principles and relationships used in various historical sacral trusses, additionally supported by contemporary literature, was applied to a village house truss from 1774 in Vápenná, Jeseníky district of the Czech Republic. Spatial numerical model of the roof structure was created in order to perform a static analysis of the roof structure in accordance with present standards. With regard to the structural analysis results, it can be said that the original design of the structure based on geometrical principles satisfy the reliability conditions defined by current European standards for structural design.
\end{abstract}

\section{Introduction}

The analysis of proportional relationships in a rural house is based on historical-structural, archival and dendrochronological research of the object as a whole. The objective of this research is not only the analysis of truss's proportions, but also its relationship to the ground plan, whose concept is based on proportional relationships as well. The principle suggested by the contemporary literature as one of the possible means of designing the truss height has been clearly identified in case of historical trusses of sacral buildings from Slovakia, which we have previously analysed [3, 5], as well as in case of the researched secular house from Vápenná in the Czech Republic.

\section{Building-historical development}

House no. 98 in Vápenná, Jeseník region, Czech Republic (Fig. 1) was built in the 2nd half of the 18th century as a reflection of establishment's aims to raise the numbers of tax-

* Corresponding author: krusop@wp.eu 
paying subjects [3]. The first written note originates in 1786, when Michal Hauke sold the house to his son, Michal [1]. Dendrochronological analysis of the ceiling - after 1775 is also an evidence for the house being built in the 2 nd half of the 18 th century $70 \mathrm{~s}$. The building is a typologically common rural house with a central room and a hood kitchen, but has been richly designed to contain decorations in form of painted red frames, which have been preserved in the western attic area. Despite the ceiling parts being largely preserved above the ground floor, the truss was newly built (1974/75 according to dendrochronological dating) with an inclusion near the southern gable.

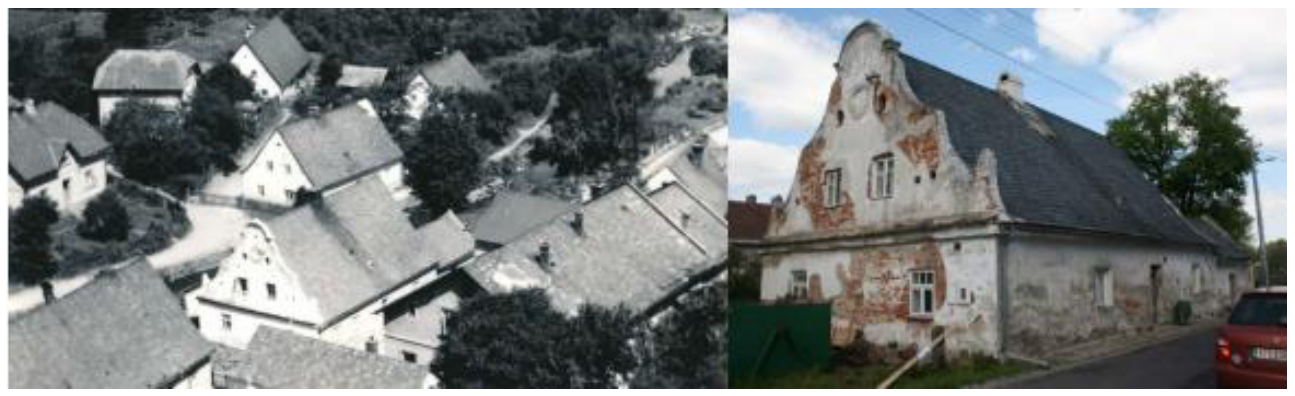

Fig 1. The researched object - a rural house no. 98 in Vápenná

\section{Truss construction}

The building has a gable roof finishing with masonry gables. The main south facade has an ornate Baroque gable with windows and vents. Roof truss structure consists of two separate truss structures with a transition portion, which form a space with the same ridge height. The truss structures can be divided as follows: over the hall structure, south side of the building and the structure above the rooms in the northern part.
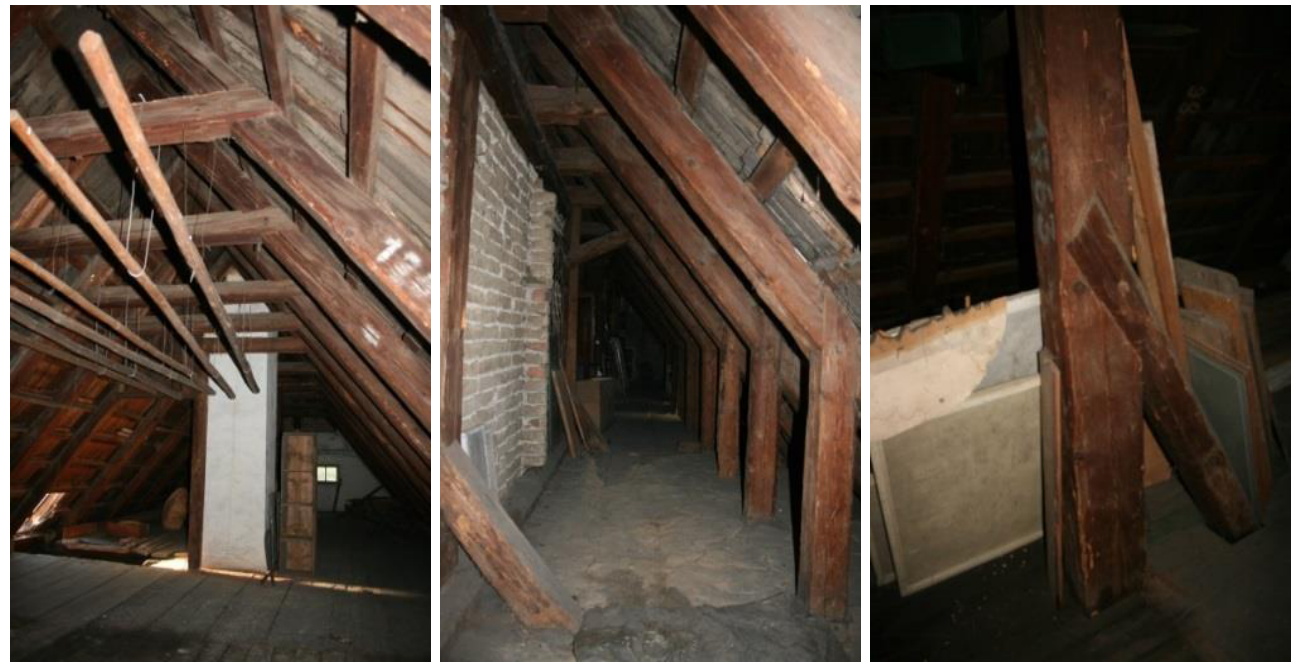

Fig. 2. The inner view of the truss 
The truss over the southern part has a rafter - collar tie structure and consists of two collar tie levels and base struts located at the base of the rafters. Lateral stools, whose posts are placed on the threshold beams, were later incorporated into the design. Central binding rafters bearing the collar beams are tenoned to the posts. The posts are also stabilized using single-sided outer bracing structures clad together into binding beams. The posts in the marginal joints are longitudinally wind-braced by struts (three views of the truss are on the Fig. 2).

The truss over the northern part is also of a rafter - collar beam structure with two collar beam levels, positioned at the same height as in the southern part. Unlike the southern roof its central posts are located in the marginal joints, which are placed on the threshold beam. The posts are stabilized by base struts. The truss itself is longitudinally secured by inclined bracing structures passing through the anchor post into the columns and the anchor posts below the lower collar beams.

\section{Geometric concepts and proportional relationships within the truss}

After previous examinations of historical trusses of primarily sacral buildings it was found that one of the most commonly used principles for determining the essentials truss dimensions is a principle we dubbed "n plus one" [4]. It is a principle determining the height of a truss based on its width as follows: the width is divided into $2 \mathrm{n}$ units and the height is then $(n+1)$ units. The same principle was applied in case of the rural truss in Vápenná, with $\mathrm{n}=5$ and the ratio between the width and height of the truss being $10: 6$ (= $5: 3$ ). A basic square ABCD dimensions are $5 \times 5$ units was obtained (Fig. 3a, b). The unit used for determining the truss height based on its width is also five times the measure of length corresponding to the span (contemporary measure), in this case $19.3 \mathrm{~cm}$ [8]. The used measure (span) was found on the top side of the ceiling beam in the form of an engraved circle (Fig. 4b). (The cut of the beam with the engraved circle was included in the depository construction details Technical University of Ostrava under inventory number 176. A, [2].)
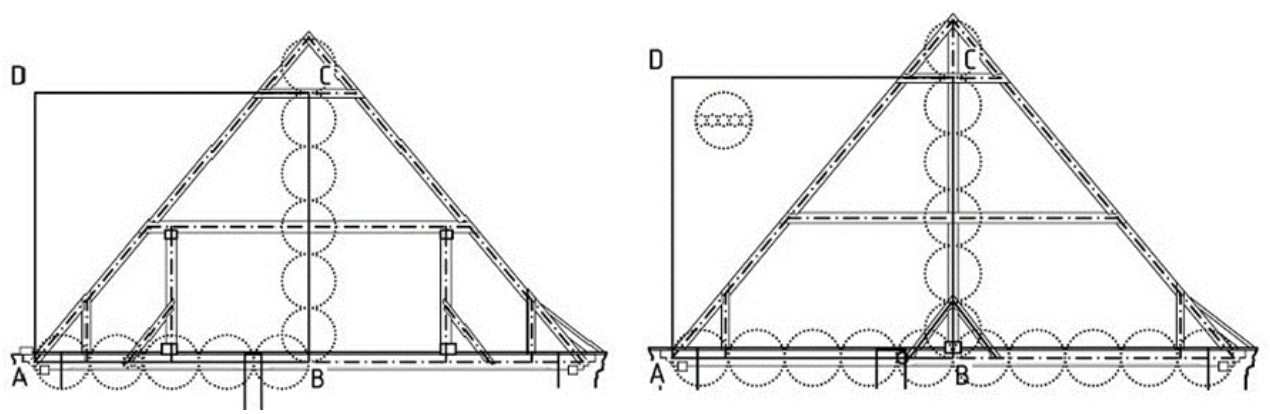

Fig.3. (a) Section of the south truss; (b) Section of the north truss.

For the design of the remaining important elements of buildings and trusses were formerly used a simple integer ratio, in the literature often named as "music" ratios [6,7]. In the researched truss were used these ratios: the main collar tie is located at half of the height of the base square; upper collar tie is located at the height of the basic square; struts and rafters are placed on the tie beam in one tenth of the total width of the truss. The floor plan of the rural house (Fig. 4a) in relation to the truss is designed in such a way that the relationship between its length and width is $3: 2$, this relationship expressed by a span is $75: 50$. The 
original big front room on the South side of the house has internal dimensions in the same proportion as the entire floor plan of the house, hence the 3:2 (45:30).
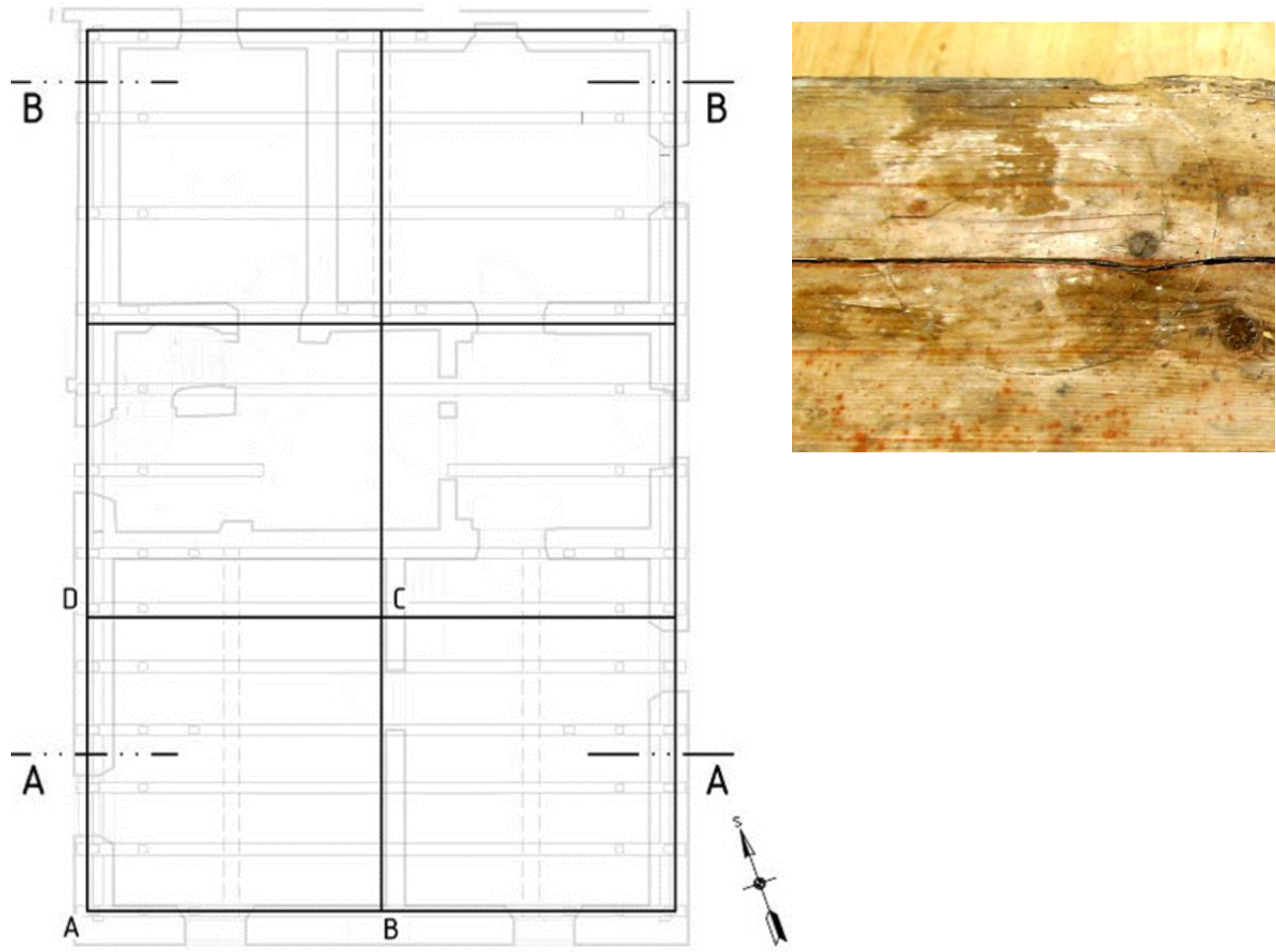

Fig. 4. (a) Floor plan; (b) Engraved circle

\section{Static analysis of the roof structure}

\subsection{Description of the numerical model}

Numerical model of the roof structure was developed in the finite element analysis (FEA) software SCIA Engineer [10]. The roof structure is modelled as three dimensional structure with beam elements. All member connections are modelled as hinge joints. Considering the stresses in the roof members and structural parameters being analysed, the isotropic material model with mechanical properties of $\mathrm{C} 24$ according to [11] is adopted, which corresponds to the applied type of wood. The geometry of numerical model is related to the roof structure's geometrical analysis presented hereinbefore. Visualization of the numerical models are presented in Fig. 5.

All the member connections are modelled as hinge joints with axial rigid connection and with capability of initial slip of $1 \mathrm{~mm}$ in the axial direction of member in order to consider an influence of gaps, cracks and geometry imperfections, occurring in historical carpentry joints. The tie beams of the secondary trusses are connected to the bottom chords of the longitudinal truss by joints, which are able to transfer only compression forces. The effect of local weakening of the cross sections by carpentry joints is neglected in the models. 
The roof superstructures were loaded according to European standards [12, 13, 14] by permanent load (self-weight and weight of roofing) and variable loads (wind actions and snow loads). The self-weight load was generated by the FEA software. The combinations of load cases were generated according to the standard STN EN 1990 [12].
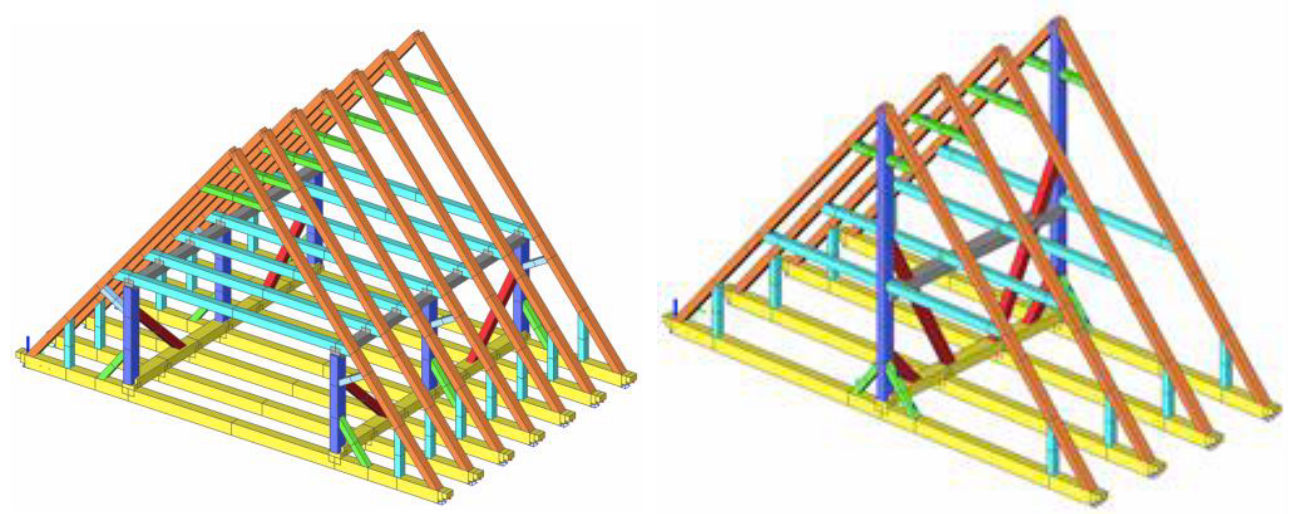

Fig. 5. Visualization of numerical models of the south truss (a) and the north truss (b).

MAIN CROSS TRUSS
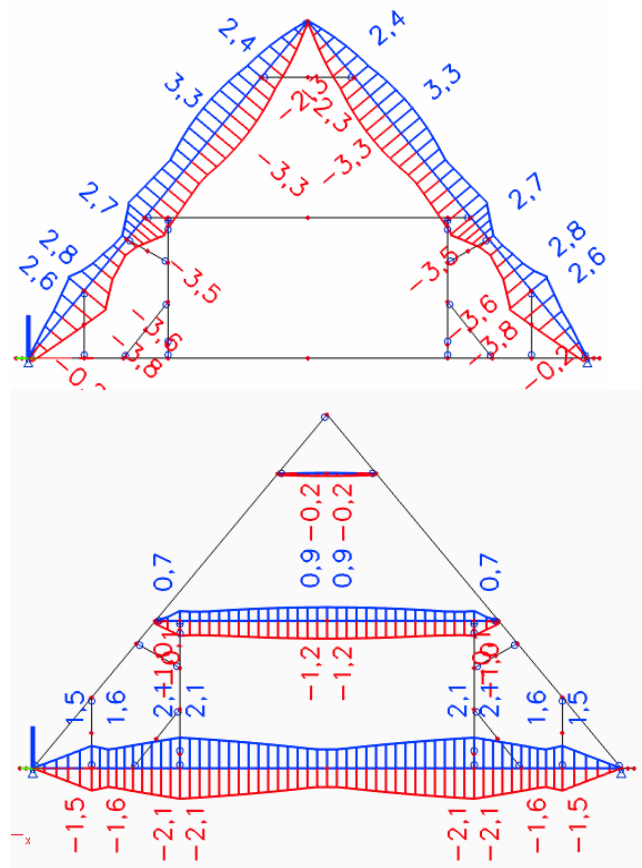

SECONDARY CROSS TRUSS

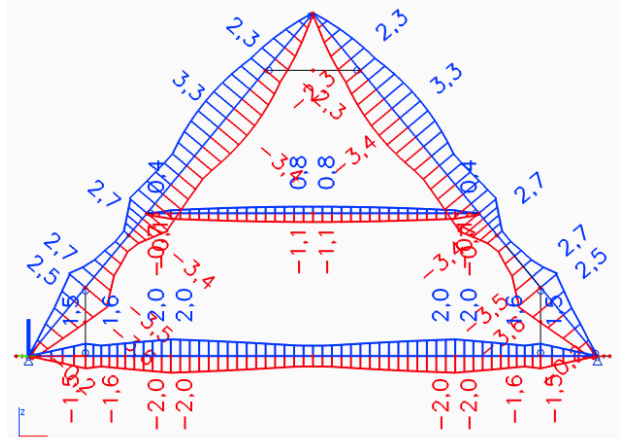

Fig. 6. Normal stresses (MPa) in the major cross truss members of the south truss. 


\subsection{Results of the numerical analysis}

The results of numerical analysis are presented by the values of maximum tensile and compression stresses and displacements in the major structural members of the trusses, calculated for the decisive load combinations. The envelopes of maximum and minimum normal stresses in the major cross truss members are presented in Fig. 6 and Fig. 7. The presented values do not include possible buckling effects, which are negligible because of low share of compression forces (caused mainly by permanent loads). The envelopes of deformations caused by characteristic load combinations are presented in Fig. 8 and Fig. 9. Based on the results of numerical analysis it can be stated out that the normal stresses in all truss members do not exceed the design values of bending and compression strength equal to 16.60 $\mathrm{MPa}$ and 14.53 $\mathrm{MPa}$, respectively, determined according to STN EN 1995-1-1 [15], assuming the timber strength class $\mathrm{C} 24$, modification factor $\mathrm{kmod}=0.9$ and partial safety factor $\gamma \mathrm{M}=1.3$.

Normal stresses in the longitudinal truss members induced by the considered loads are negligible. The longitudinal truss represents mainly a longitudinal brace system ensuring the global stability of the roof structure. In addition, it ensures the load redistribution between the individual cross trusses in the case of their depression as a consequence of damaged joints or members during the life cycle of the roof structure.

MAIN CROSS TRUSS

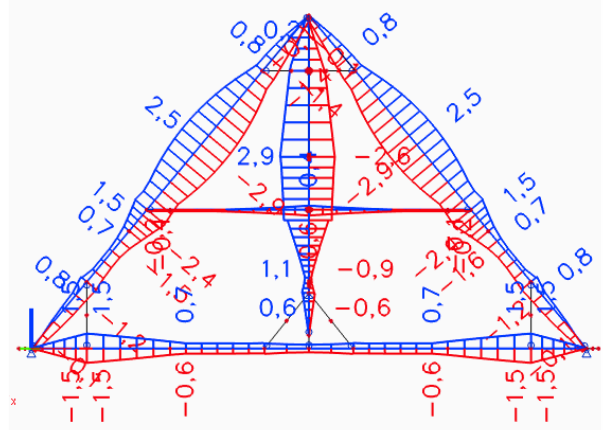

SECONDARY CROSS TRUSS

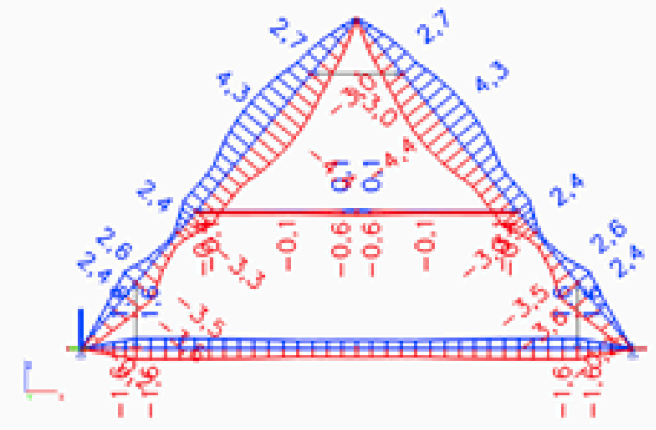

Fig. 7. Normal stresses (MPa) in the major cross truss members of the north truss.

MAIN CROSS TRUSS

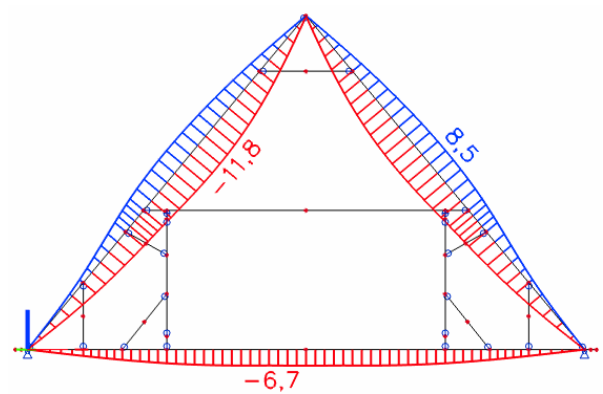

SECONDARY CROSS TRUSS

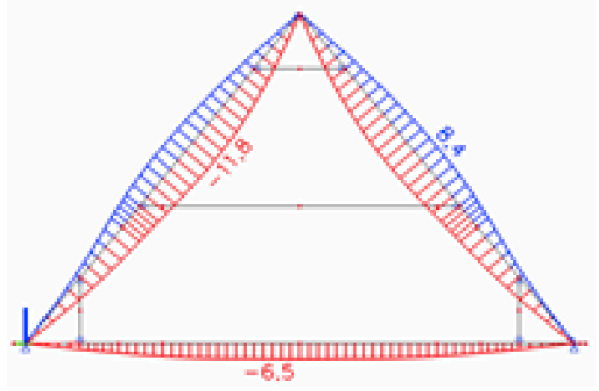

Fig. 8. Vertical deformations $(\mathrm{mm})$ in the major cross truss members of the south truss. 
MAIN CROSS TRUSS

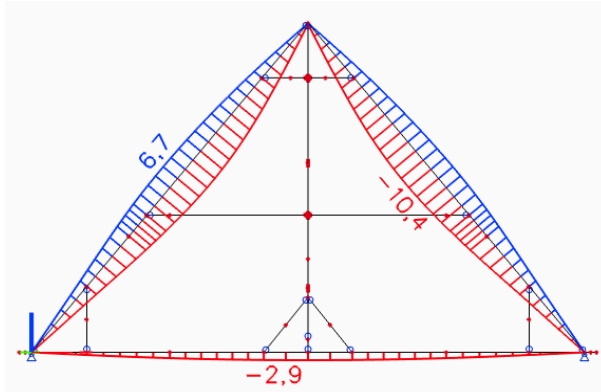

SECONDARY CROSS TRUSS

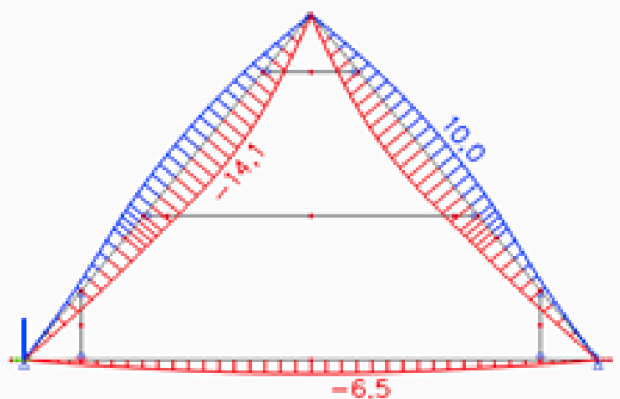

Fig. 9. Vertical deformations $(\mathrm{mm})$ in the major cross truss members of the north truss.

\section{Conclusion}

There has been identified the geometrical and proportional concept of truss design on the researched object, in relation to the concept of the object floor plan, which is based on the use of contemporary system of measure. Geometric and proportional analysis of the original concept design of the truss and the object itself may be helpful in understanding the historical development of the object, used historical measures, proportions and structures. Knowledge of ratios and geometric concepts can highlight the impacts of cultural and socio-economic links with architecture in the region. Reached knowledge about proportional concept can be a guide for the methodology of recovery in relation to heritage preservation of historical objects.

To conclude, we can say that the observed Baroc truss is geometrically and proportionately very consistently designed with an emphasis on high level of reliability. The roof superstructure consists of quite massive solid elements, which results in quite high reliability of the roof structure. It can be assumed that with regard to great importance of the Rural House in Vápenná Village, there were high demands on the reliability and durability of the roof structure above the presbytery. Of course, it had to comply with adequate financial resources for realization of the building.

\section{References}

1. L. Augustinková Venkovský dům čp. 98 ve Vápenné (k. ú. Vápenná, parc. č. 95). Stavebně historický průzkum. Ostrava 2013. Nepublikovaný materiál uložený na NPÚ, ú.o.p. v Olomouci.

2. L. Augustinková Předměty z venkovského domu čp. 98 ve Vápenné. In: Augustinková, L. - Krušinský, P. (edd.) Předměty $\mathrm{z}$ depozitářů stavebních detailů v Ostravě a v Žilině. Ostrava (2015)

3. P. Krušinský, E. Capková, J. Gogál, Advanced Materials Research 1122 (2015)

4. P. Krušinský, E. Capková, J. Gogál, M. Holešová, Civil and environmental engineering 11/2 (2015)

5. P. Krušinský, E. Capková, J. Gogál, M. Kekeliak, Advanced materials research 969 (2014)

6. A. Struhár, Geometric harmony of historical architecture in Slovakia. Bratislava. Pallas (1977) 
7. R. Wittkover, Architectural Principles in the Age of Humanism. W. W. Norton \& Company. (1971)

8. J. Heurich, Przewodnik dla cieśli obejmujący cały zakres ciesielstwa z 299 drzeworytami w tekście. Warszawa 1871. (Reprint 2010)

9. M. Holešová, Selected geometrical constructions, Acta mathematica 17 : conference proceedings of international conference 12th mathematical conference, Slovakia, Nitra, (2014)

10. SciaEngineer 2010. Software for structural analysis. http://nemetschek-scia.com/sk

11. STN EN 338 Structural timber. Strength classes. SÚTN, Bratislava (2004)

12. STN EN 1990 Eurocode. Basis of structural design. SÚTN, Bratislava (2009)

13. STN EN 1991-1-1 Eurocode 1. Actions on structures. Part 1-1: General actions. Densities, self-weight, imposed loads for buildings. SÚTN, Bratislava (2007)

14. STN EN 1991-1-3 Eurocode 1. Actions on structures. Part 1-3: General actions. Snow loads. SÚTN, Bratislava (2007)

15. STN EN 1991-1-4 Eurocode 1. Actions on structures. Part 1-4: General actions. Wind actions. SÚTN, Bratislava (2007)

16. STN EN 1995-1-1 + A1 Eurocode 5. Design of timber structures. Part 1-1: General. Common rules and rules for buildings. SÚTN, Bratislava (2008) 